\title{
Substrate-Induced pH Changes and Process Stability of Anaerobic Digestion of Shea Waste
}

\section{${ }^{1}$ MARTIN AMPADU OFOSU, ${ }^{* 2}$ MELVIN-GUY ADONADAGA; ${ }^{3}$ ISAAC SACKEY; ${ }^{2}$ BOATENG AMPADU}

\author{
${ }^{*}$ Department of Agric. Mechanization and Irrigation Technology, University for Development Studies, Tamale, Ghana \\ ${ }^{* 2}$ Department of Environmental Science, CKT-University of Technology and Applied Sciences, Navrongo, Ghana \\ ${ }^{3}$ Department of Applied Biology, University for Development Studies, Navrongo, Ghana \\ *Corresponding Author Email: madonadaga@cktutas.edu.gh; Tel: +233244825025
}

\begin{abstract}
Shea butter extraction involves the generation of waste of environmental concern. To help find a solution to the management of this waste, and to search for an alternative source of energy, this study was carried out to investigate the potential of shea waste in generating methane gas through anaerobic digestion. At high concentrations, volatile fatty acids produce a low $\mathrm{pH}$, which may inhibit hydrolysis, thereby affecting the stability of the anaerobic digestion process. The influence of $\mathrm{pH}$ changes on process stability (or otherwise) was also investigated. The study involved two fermentation processes: mono-fermentation and co-fermentation involving a mix of shea waste and cattle dung. The mono-fermentation investigations comprised six treatments - three organic dry matter concentrations of $7 \%$, $5 \%$ and $3 \%$, combined with two hydraulic retention times of 30 and 60 days. The co-fermentation investigations comprised three treatments of shea waste and cattle manure mix in proportions (by volume) of 50:50, 75:25 and 90:10. The results showed that changes in $\mathrm{pH}$ were a good parameter for indicating process instability. The results also showed that monofermentation of shea waste was not a viable option in anaerobic digestion for biogas production, whilst only the substrate with $50 \%$ cattle manure in the co-fermentation trials showed process stability, producing biogas with adequate methane content.
\end{abstract}

\section{DOI: https://dx.doi.org/10.4314/jasem.v24i12.4}

Copyright: Copyright $\left({ }^{\circ} 2020\right.$ Ofosu et al. This is an open access article distributed under the Creative Commons Attribution License (CCL), which permits unrestricted use, distribution, and reproduction in any medium, provided the original work is properly cited.

Dates: Received: 17 October 2020; Revised: 23 November 2020; Accepted: 27 November 2020

Keywords: Anaerobic digestion, co-fermentation, mono-fermentation, process stability, shea waste, biogas

Anaerobic digestion (AD) is brought about by a consortium of interdependent and symbiotic populations of heterotrophic microorganisms, mainly bacteria, which are capable of utilizing a diverse spectrum of substrates in the absence of oxygen for the synthesis of new cellular materials and production of various end-products (Yang et al., 2015). The interdependence of the microorganisms or bacteria is a key factor of the biogas process. The rate at which the bacteria grow is of paramount importance in $\mathrm{AD}$ process (Wei et al., 2014). This rate can be enhanced by the operating parameters of the digester, leading to an increase in the anaerobic degradation efficiency of the system. Each of the various types of bacteria responsible for the four metabolic stages (hydrolysis, acidogenesis, acetogenesis and methanogenesis) is affected differently by those parameters (Shi et al., 2014) and interactive effects between the various determining factors are possible. However, it is only these factors and their respective qualitative effects on the process of fermentation that can be predicted. Various factors such as biogas potential of feedstock, design of digester, inoculum, nature of substrate, $\mathrm{pH}$, temperature, loading rate, hydraulic retention time (HRT), C:N ratio and volatile fatty acids (VFA) influence biogas production (Banks et al., 2012; Nagao et al., 2012; Zhang et al., 2013). It is necessary that the aspects of the anaerobic digestion processes of hydrolysis or liquefaction and methanogenesis be well balanced. If the methane bacteria are absent, the digestion process may only succeed in hydrolysing the material and may render it more offensive than the original material. On the other hand, if hydrolysis occurs at a faster rate than methanogenesis, the resultant accumulation of acids may inhibit the methane bacteria and the bioconversion process as well (Zhang et al., 2014). In a well-balanced anaerobic digestion process, all products of a previous metabolic stage are converted into the next one without significant build-up of intermediary products (Veeken et al., 2000). The most common disturbances causing imbalance are hydraulic or organic overloading, the presence of inorganic or organic toxins or other disturbances in the process conditions such as 
temperature and substrate changes (Razaviarani et al., 2013; Nagao et al., 2012). Even though fats (lipids) are fairly rapidly degraded, they may be the reason for problems associated with its own degradation. Lipids and their hydrolysis products, the long chain fatty acids (LCFA), might adsorb to surfaces and as such hinder (physically) the attack of exo-enzymes, which hydrolyse the substrate, and the transport of substrates through bacteria membranes (Romero et al., 2016; Subramanian et al., 2015). High concentrations of LCFA are also known to inhibit its own degradation and also methane formation (Paudel et al., 2017; Lindner et al., 2016; Voelklein et al., 2016). The shea tree (Vitellaria paradoxa) is a major cash crop which grows wildly in savanna and sahelian vegetations. Shea nuts contain $40-55 \%$ fat, of which 5-9\%, 30$41 \%, 49-50 \%$ and $4-5 \%$ are palmitic acid, stearic acid, oleic acid, and linoleic acid, respectively (Head et al., 1995). According to Head et al. (1995), industrial extraction by screw press remove only $30-35 \%$ of fat with the remaining fat being left in the shea waste. In Ghana, at least an estimated 60,000 metric tons of shea nuts are collected annually for local processing for the fat (Ofosu and Aklaku, 2010). It is estimated that for every metric ton of nuts processed, $450-600 \mathrm{~kg}$ of waste is produced. This waste has the potential to pollute the environment and, therefore, needs to be disposed of properly. Anaerobic digestion of the shea waste to generate methane is a possible option to deal with the waste problem. In order to develop suitable fermentation technologies for this purpose, basic information is required on vital parameters of the biogas production. The objective of the study is to investigate the influence of substrate $\mathrm{pH}$ on the stability of anaerobic digestion in mono- and cofermentation of shea waste for biogas/methane production under continuous-flow system.

\section{MATERIALS AND METHODS}

The study was conducted in the Biogas Laboratory of the Faculty of Agriculture, University for Development Studies, with six 74-litre horizontal, half-technical fermentation units. Each fermentation unit comprised a digester (fermenter) with a manual stirrer, a pressure compensation bottle, and a gasholder with a counterweight and a scale. A schematic diagram of the fermentation unit and its accessories are shown in Figure 1.

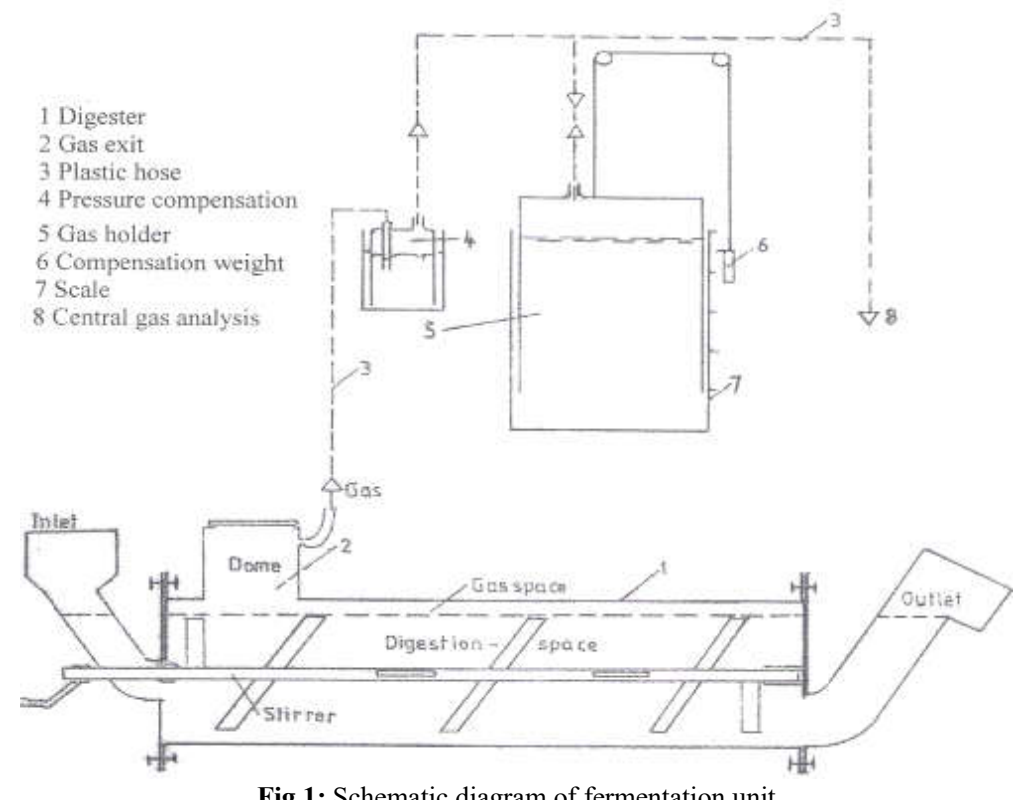

Fig 1: Schematic diagram of fermentation unit

Collection of raw input substrates and determination of physico-chemical characteristics: The shea waste used for the investigations was periodically collected from Shebu Industries at Savelugu, a distance of 22 $\mathrm{km}$ north of Tamale. The shea waste was subsequently stored in polypropylene sacks at ambient conditions in the laboratory. Fresh cattle dung was also collected daily from a kraal at Kpachi, a nearby village about 2 $\mathrm{km}$ from the Nyankpala Campus of the University.
The raw shea waste and cattle dung were analyzed for the following properties using standard procedures: dry weight, organic dry matter, ash content, moisture content, nitrogen and carbon content, raw fibre, raw fat and $\mathrm{C}: \mathrm{N}$ ratio.

Preparation of inoculum and input substrate: Microorganisms in cattle-dung were cultured to produce the inoculum for the experiment by mixing 
cattle dung with water in a ratio of $1: 1$ by weight. Each digester was filled with this cattle-dung slurry and the substrate allowed to stand for two weeks. An initial shea-waste to water ratio of $1: 7$ by weight, that gave an organic dry matter (odm) concentration of approximately $11 \%$, was prepared by soaking the measured weight of shea waste in the measured quantity of water for about 30 minutes in order to acquire fluid properties. Further sample dilutions were undertaken to obtain the appropriate odm concentrations required for the experiments.

Experimental treatments: The mono-fermentation trial consisted of six treatments: three odm concentrations of $7 \%, 5 \%$ and $3 \%$ combined with two hydraulic retention times (HRT) of 30 and 60 days. All treatments proceeded at ambient conditions without temperature control. The appropriate odm concentrations of $7 \%, 5 \%$ and $3 \%$ of shea waste were prepared daily and fed to the corresponding digesters in quantities based on the HRT. In the co-fermentation trials, shea waste and cattle dung were mixed in varying proportions. To determine the optimum sheawaste to cattle-dung ratio for the anaerobic digestion and to ensure process stability, three co-fermentation treatments were chosen: shea-waste to cattle-dung ratios (by volume) of 50:50, 75:25 and 90:10. Organic dry matter concentration of $7 \%$ for all treatment substrates and HRT of 30 days were chosen as this ensured high digester-specific biogas production. Each treatment was duplicated for both trials.

Daily operations: Digester feeding, as well as gas and substrate parameter readings was carried out daily in the morning between 9.30 am and $10.30 \mathrm{am}$. Input substrates were always prepared before readings were taken so that the digesters could be fed immediately after the readings had been taken. Approximately 2.6 $\mathrm{kg}$ of fresh substrate for feeding the digester was measured daily using Soehnle weighing scale. The contents of the digesters were stirred before and after feeding to ensure uniformity and consistency in the effluent from the digester as well as an even distribution of bacteria within the substrate. Ten revolutions of stirring were undertaken at any of these times. The ambient temperature as well as the relative humidity of the laboratory was continuously recorded using Casella Standard thermo-hygrograph.

Determination of biogas parameters: The volume of biogas produced was determined daily by the position of the pointer on the counterweight on the calibrated scale attached to the gasholder. Analysis of the biogas to determine its quality (composition), namely, methane-, carbon dioxide and hydrogen sulphide- contents, was carried out using gas analyzer Sewerin SR2-DO by connecting the probe of the gas analyser to the exit pipe of the gasholder. To reduce the amount of water vapour exposure on the equipment and to protect the equipment against excessive corrosion, a portion of the pipe (about $2 \mathrm{~cm}$ long) through which the biogas was directed to the equipment for analysis was filled with anhydrous calcium chloride $\left(\mathrm{CaCl}_{2}\right)$ powder.

Determination of substrate parameters: $\mathrm{pH}$ values of the input and outflow substrates were measured daily using a digital pH-meter WTW $\mathrm{pH} 323 \mathrm{~A}$ through $\mathrm{pH}$ electrode Sentix 41. During the measurements, the $\mathrm{pH}$ electrode was kept in the substrate until the reading had stabilized. The temperature of the digester content was measured daily with a digital thermometer Checktemp- 01 by inserting about $8 \mathrm{~cm}$ of the thermometer probe into the substrate until the reading was stable. Total solids and organic dry matter contents of input substrate were also determined daily, whilst those of the outflow substrate were determined at weekly interval. To determine the total solids (dry weight), a sample of the substrate up to $35 \mathrm{~g}$ was placed in a Wagtech ventilated oven at a temperature of $106^{\circ} \mathrm{C}$ for 24 hours. Top loading electronic balance Mettler PM 480 Delta Range was used in the weight measurements. To determine the organic dry matter (volatile solids) of the substrate, the dry matter removed from the ventilated oven was afterwards placed in a Gallenkamp muffle-furnace at a temperature of $530{ }^{\circ} \mathrm{C}$ for 4 hours. The corresponding loss in weight after burning in the furnace was thus the odm content or the volatile solids (VS) of the sample. All line graphs were drawn using Microsoft Excel 2010.

\section{RESULTS AND DISCUSSION}

Characteristics of raw shea waste and cattle dung: The characteristics of the basic raw materials (shea waste and cattle dung) as well as the various concentrations and types of input substrates used for the digestion process are summarized in Tables 1 and 2. The characteristics of cattle dung may change with the season. Between the months of May and November, cattle in the Northern region of Ghana graze on green vegetative material and also have access to a lot of water. This accounted for the high moisture content of the raw cattle dung. The $\mathrm{pH}$-values of the basic substrate, shea waste, under all odm concentrations, as well as those of the shea waste and cattle dung mix at $7 \%$ odm fell below the optimal $\mathrm{pH}$ range of 6.8-7.2 (Abdel-Hadi, 2003) for anaerobic digestion of organic materials (Table 2). 
Table 1: Characteristics of raw shea waste and cattle dung used

\begin{tabular}{|c|c|c|}
\hline \multirow[b]{2}{*}{ Parameter } & Shea waste & Cattle dung \\
\hline & $\begin{array}{l}\text { In fresh raw } \\
\text { material }(\%)\end{array}$ & $\begin{array}{l}\text { In fresh raw } \\
\text { material }(\%)\end{array}$ \\
\hline Dry weight, TS & 90.8 & 17.7 \\
\hline Organic dry matter, odm & 85.9 & 14.1 \\
\hline Ash content & 4.9 & 3.6 \\
\hline Moisture content & 9.2 & 82.3 \\
\hline Nitrogen & 1.34 & 1.54 \\
\hline Carbon & 47.83 & 40.86 \\
\hline Raw fibre & 6.9 & - \\
\hline Raw fat & 12.5 & - \\
\hline $\mathrm{C}: \mathrm{N}$ ratio & $36: 1$ & $27: 1$ \\
\hline
\end{tabular}

Table 2: $\mathrm{pH}$-values of input substrates

\begin{tabular}{llllllll}
\hline & \multicolumn{3}{l}{ Shea waste $100 \%$} & Cattle dung $100 \%$ & \multicolumn{3}{l}{ SH:CD mix at $7 \%$ odm } \\
\hline Mean odm & $3 \%$ & $5 \%$ & $7 \%$ & $7 \%$ & $50: 50$ & $75: 25$ & $90: 10$ \\
Mean pH-value & 5.69 & 5.58 & 5.50 & 7.03 & 6.68 & 6.37 & 6.09 \\
\hline
\end{tabular}

SH: Shea waste; CD: Cattle dung

Biogas yield and quality: The experiments under mono-fermentation of shea waste were terminated at two stages, depending on which occurred first: first, when the biogas production declined to near-zero levels and secondly, when the methane content declined below $50 \%$ by volume of biogas. This was because biogas with less than $50 \%$ methane content is not combustible (Alastriste-Mandragon et al., 2006). Shea waste had a high potential to generate substantial amount of methane. At the peak of production for the 60-day HRT, substrate-specific biogas yields at 3\%, $5 \%$ and $7 \%$ odm concentrations were $610 \mathrm{l} / \mathrm{kg}$ odm, $510 \mathrm{l} / \mathrm{kg}$ odm and $580 \mathrm{l} / \mathrm{kg}$ odm, respectively, with corresponding methane contents of $66 \%, 63 \%$ and $62 \%$ by volume of biogas. Biogas quality was based on the percentage of its methane content. The methane contents at 60-day HRT at all the three odm concentrations were neither significantly different nor consistent in any manner, but ranged between $54 \%$ and $67 \%$ by volume of biogas. At $5 \%$ odm at 60 -day HRT, the methane content dropped initially from $58 \%$ by volume biogas to $56 \%$, rising to $65 \%$ and then dropping again to $60 \%$ on the $50^{\text {th }}$ day when the experiment was terminated. A similar trend of an increase in methane content following an initial drop was observed for both $3 \%$ and $7 \%$ odm concentrations. The methane content for 30-day HRT at all three odm concentrations showed a gradual decline right from the beginning of the experiments. The rate of decline in methane content was, however, variable with $7 \%$ odm experiencing the fastest decline, whilst the slowest decline was observed at $3 \%$ odm. At $3 \%$ odm, the methane content ranged between $50 \%$ and $56 \%$, with the experiment terminating on day 29. The methane content at $5 \%$ odm ranged between $49 \%$ and $57 \%$, with the experiment terminating on day 18 , whilst at 7 $\%$ odm, the methane content ranged between 42 and $56 \%$, with the experiment terminating on day 12 . In general, the mean methane contents at all three odms for the 60-day HRT were substantially higher than the methane contents obtained for the 30-day HRT at all three odms. The highest mean methane content of 62.8 $\%$ was attained at 60 -day HRT and at $3 \%$ odm, whilst the lowest value of $48.7 \%$ was attained at 30 days HRT and at $7 \%$ odm. Figure 2 shows the methane content of biogas produced for the co-fermentation trials at ambient temperature and HRT of 30 days. Digester feeding for 90:10 and 75:25\% shea-waste to cattle-dung ratio treatments was terminated on day 17 and 25 , respectively, when methane content of the biogas produced fell below $50 \%$. On day 17 , methane contents of biogas from the 50:50, 75:25 and 90:10 shea-waste to cattle-dung ratio treatments were $60 \%$, $50 \%$ and $42 \%$, respectively. On day 25 , the methane contents of the biogas from the remaining two treatments, 50:50 and 75:25 shea-waste to cattle dung ratio were $64 \%$ and $44 \%$, respectively, thereby confirming the stability of the $50: 50$ process. In general, treatment with shea-waste to cattle-dung ratio of 50:50 was the most feasible anaerobic digestion option, achieving a mean methane content of $60.9 \%$ for the entire period of the experiment. The trend of fall and rise in methane content levels in cofermentation of organic wastes with cattle manure observed appears to be peculiar to anaerobic digestion of fatty substrates as reported by Amon et al. (2002).

Daily methane yield: Biogas/methane production under mono-fermentation of shea waste was highly unstable. No steady phase was attained in any of the treatments during the period of the experiment as shown in Figures $3 \mathrm{a}$ and $3 \mathrm{~b}$. In all cases, gas production after reaching the peak declined on a daily basis, despite the daily feeding, to such low levels that the experiments had to be terminated at different times depending on the gas production trend. In all treatments, gas production decrease was slowest at 3\% odm and fastest at $7 \%$ odm. 


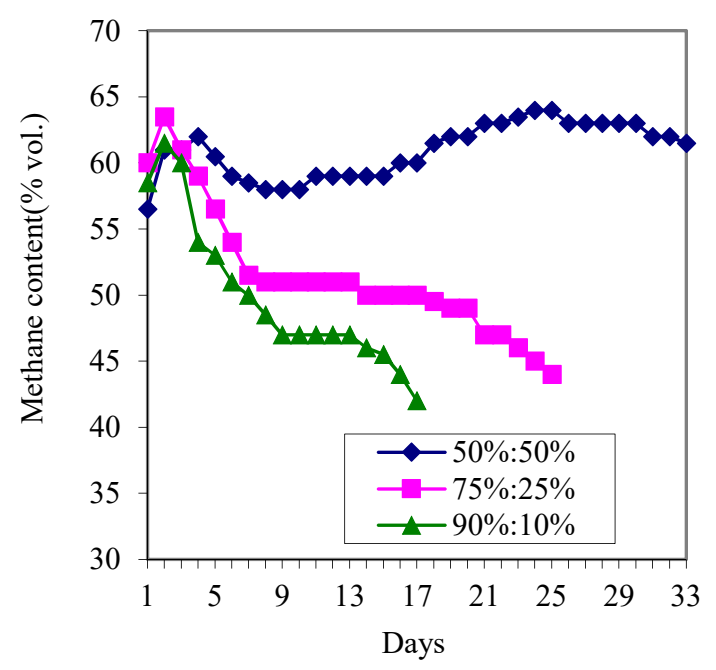

Fig 2: Methane content of biogas produced in co-fermentation

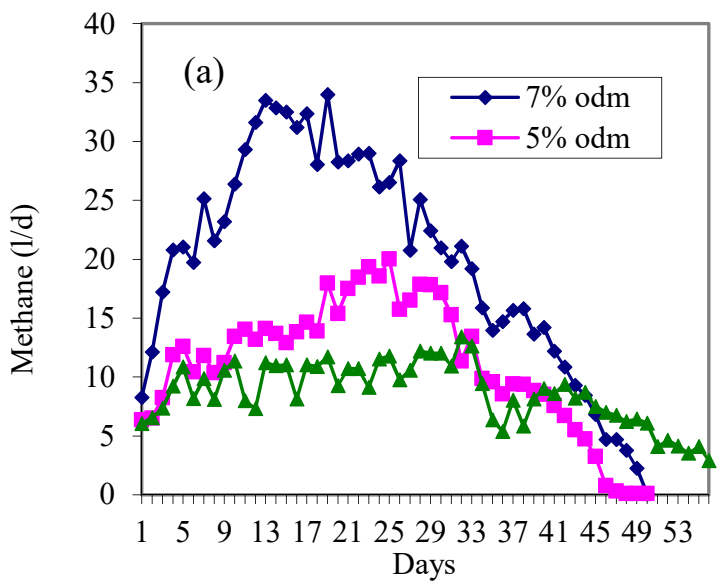

Fig 3a: Daily methane production in mono-fermentation (a) 60-day HRT

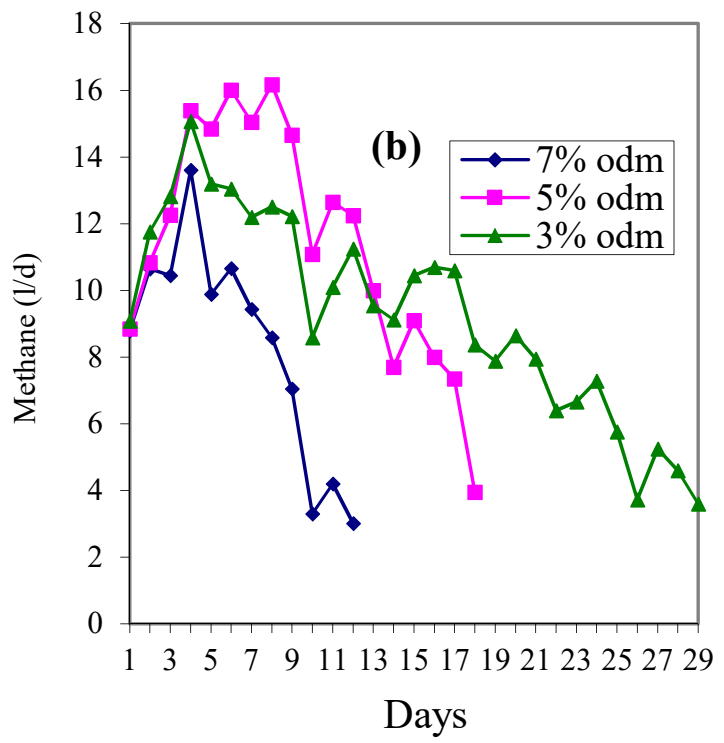

Fig 3b: Daily methane production in mono-fermentation 30-day HRT
Figure 4 shows the daily methane yield at the various shea-waste to cattle dung ratios for the cofermentation trials. Daily methane yield paralleled that of methane content of biogas produced (see Figure $3 b)$. During the first 17 days of the fermentation process when methane production rates from the 75:25 and 90:10 shea waste and cattle dung mix were declining, that of substrate with $50 \%$ shea waste was increasing towards a steady phase. On day 17 when digester feeding for the 90:10 shea waste and cattle dung mix was discontinued due to declining methane production, mean daily methane production (litres/day) for substrates with 50:50, 75:25 and 90:10 shea waste and cattle dung mix were $31.31,13.25$ and 2.06 , respectively. On the $25^{\text {th }}$ day when methane production from 50:50 had reached a steady state of 33.41 litres, production from 75:25 had declined to 4.36 litres. The experiment for substrate 75:25 was thus terminated on the $25^{\text {th }}$ day. The process stability of substrate 50:50 was further observed and confirmed by extending the fermentation to the $33^{\text {rd }}$ day, at which time the methane yield was above 25 litres.

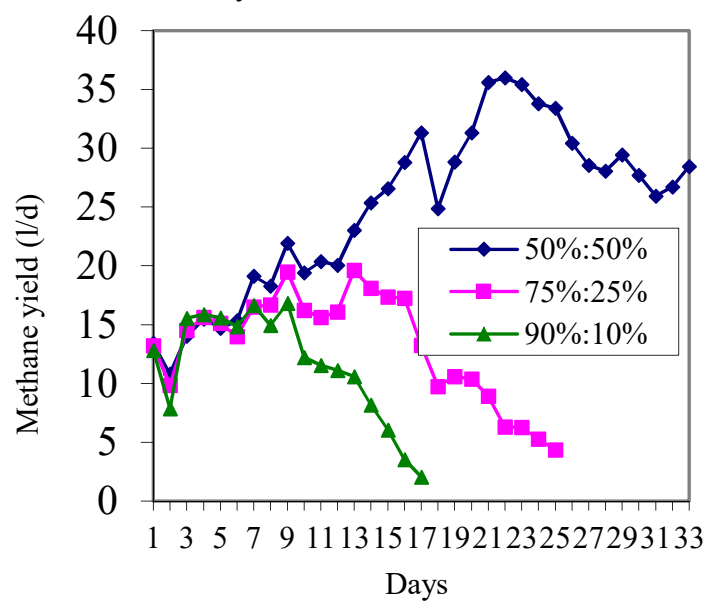

Fig 4: Daily methane yield in co-fermentation trials

Changes in $\mathrm{pH}$ of digester substrates in mono- and cofermentation trials: The results of changes in digester substrate $\mathrm{pH}$ in mono- and co-fermentation experiments are shown in Figures 5 and 6 respectively. The $\mathrm{pH}$ of the digester substrates for the monofermentation at both HRTs and various odm concentrations decreased progressively from the initial values of $>6.5$ to such low levels that biogas production was adversely affected, and this led to the eventual termination of the experiments (Figure 5). For the co-fermentation trial, $\mathrm{pH}$ for substrate 50:50 in the digester had an average value of 6.95 showing some stability in biogas production over the entire experimental period from the mean input substrate value of 6.68 (Figure 6). The $\mathrm{pH}$-values for substrates 75:25 and 90:10 in the digester showed declining trends, an indication of process instability (Figure 6). 

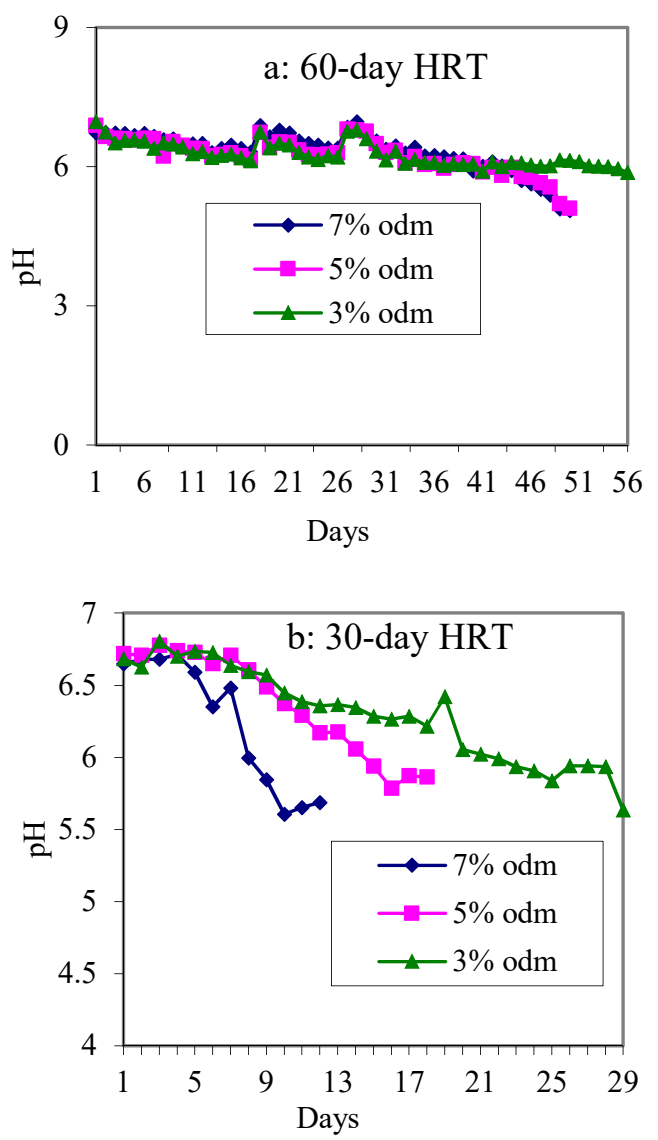

Fig 5: Changes in $\mathrm{pH}$ of digester substrates for the different odm concentrations during mono-fermentation

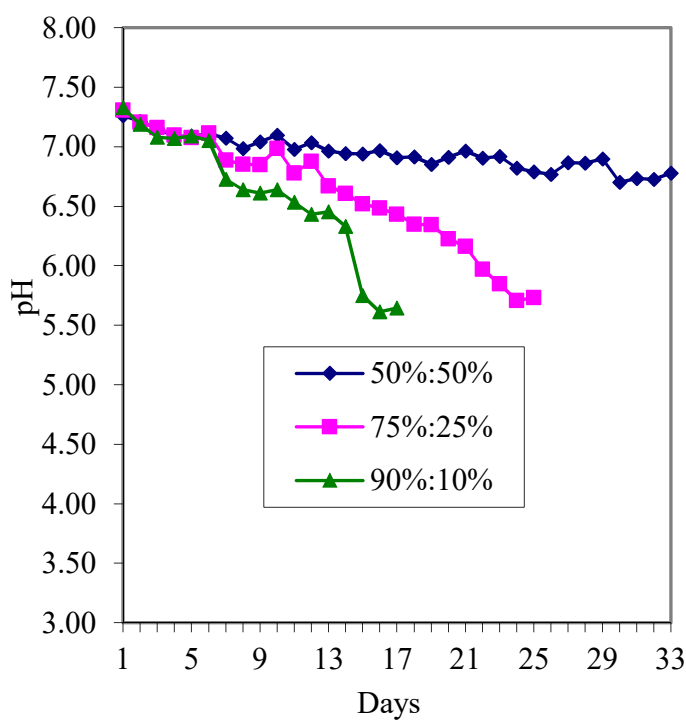

Fig 6: Changes in $\mathrm{pH}$ of digester substrates for the different odm concentrations during co-fermentation

The $\mathrm{pH}$ of a substrate is central in the determination of the process stability and efficient biogas production. Anaerobic digestion process can be inhibited at low $\mathrm{pH}$ values (Callaghan et al., 2002). Ghaly and BenHassan (1989), Hanaki et al. (1981), and Person and
Bartlett (1978) have shown that methane production proceeds quite well as long as the $\mathrm{pH}$ is maintained between 6.6 and 7.6, with an optimum range between 6.8 and 7.2. Under conditions of unstable operation, intermediates such as volatile fatty acids (VFA) and alcohols accumulate at different rates, depending on the substrate, causing instability of the process (Ahring et al., 1995). The rate of hydrolysis is a function of several factors including $\mathrm{pH}$ (Veeken and Hamelers, 1999). As noted by Veeken et al. (2000), high concentrations of VFA are accompanied by low $\mathrm{pH}$, which may inhibit hydrolysis. Similarly, Burton and Turner (2003) concluded that $\mathrm{pH}$ decrease below 6 causes an inhibition of the methane-forming bacteria leading to accumulation of volatile acids in the digester. Considering the input-pH of the three substrates it became obvious that the higher the cowdung addition the more optimal the $\mathrm{pH}$ value of the mix substrate, and the closer the $\mathrm{pH}$ value to the optimal the more stable the anaerobic digestion process.

Conclusion: Mono-fermentation of shea waste was found not to be a viable option in anaerobic digestion due to the presence of fats in the shea waste leading to low $\mathrm{pH}$. Although co-fermentation of shea waste with cattle manure was found to be feasible in the generation of methane, only substrate with $50 \%$ cattle manure addition showed process stability. Low input $\mathrm{pH}$ led to a failure of the buffering mechanism of the substrate and, consequently, affected the methane yield as well as the methane content in the biogas. Increase in the cattle manure proportion in the shea substrate improved the substrate $\mathrm{pH}$ and enhanced the process stability.

Acknowledgement: This study was conducted with support from the World Bank and Agricultural SubSector Improvement Project (AgSSIP) of the Council for Scientific and Industrial Research (CSIR), Ghana.

\section{REFERENCES}

Abdel-Hadi, M (2003). Methane generation out of food waste and beta beets. (Unpublished $\mathrm{PhD}$ Thesis). University of Hohenheim, Stuttgart, Germany.

Ahring, BK; Sandberg, M; Angelidaki, I (1995). Volatile fatty acids as indicators of process imbalance in anaerobic digestors. Appl. Microbiol. Biotechnol. 43: 559-565.

Alatriste-Mondragón, F; Samar, P; Cox, H; Ahring, B; Iranpour, R (2006). Anaerobic codigestion of municipal, farm, and industrial organic wastes: a 
survey of recent literature. Water Environ. Fed. 78: 607-636

Amon, T; Boxberger, J; Lindworsky, J; Scheibler, M (2002). Co-fermentation of organic wastes and agricultural manures. In H. Kopetz; T. Weber; W. Palz; P; Chartier; GL. Ferrero (Eds), Biomass for Energy and Industry Würzburg, Austria: C.A.R.M.E.N pp160 - 162 .

Banks, C; Zhang, Y; Jiang, Y; Heaven, S (2012). Trace element requirements for stable food waste digestion at elevated ammonia concentrations. Bioresour. Technol. 104: 127-135.

Burton, CH; Turner, C (2003). Manure management: Treatment strategies for sustainable agriculture (2nd ed.). Bedford, U.K.: Silsoe Research Institute.

Callaghan, FJ; Wase, DAJ; Thayanithy, K; Forster, CF (2002). Continuous co-digestion of cattle slurry with fruit and vegetable wastes and chicken manure. Biomass and Bioenergy 27: 71-77.

Ghaly, AE; Ben-Hassan, RM (1989). Continuous production of biogas from dairy manure using an innovative no-mix reactor. Appl. Biochem. Biotechnol. J., 20/21, 541-559.

Hanaki, K; Matsuo, T; Nagase, M (1981). Mechanism of inhibition caused by long-chain fatty acids in anaerobic digestion process. Biotechnol. Bioengg. 23: 1591-1610.

Head, SW; Swetman, AA; Hammonds, TW; Gordon, A; Southwell, KH; Harris, R.V.(1995). Small scale vegetable oil extraction. Chatham, U.K.: Natural Resources Institute.

Hohlfeld, J; Sasse, L (1985). Production and utilization of biogas in rural areas of industrialized and developing countries. GTZ No.97. Eschborn, Germany: GTZ.

Lindner, J; Zielonka, S; Oechsner, H; Lemmer, A (2016). Is the continuous two-stage anaerobic digestion process well suited for all substrates? Bioresour. Technol. 200: 470-476.

Nagao, N; Tajima, N; Kawai, M; Niwa, C; Kurosawa, N; Matsuyama, T; Yusoff, F; Toda, T (2012). Maximum organic loading rate for the single-stage wet anaerobic digestion of food waste. Bioresour. Technol. 118: 210-218.
Ofosu, MA; Aklaku, ED (2010). Determining the optimum proportion of shea waste in anaerobic cofermentation process. J. Sci. Tech. 30: 119-128.

Paudel, S; Kang, Y; Yoo, Y; Seo, G (2017). Effect of volumetric organic loading rate (OLR) on $\mathrm{H}_{2}$ and $\mathrm{CH}_{4}$ production by two-stage anaerobic codigestion of food waste and brown water.

Person, S; Bartlett, HD (1978). Converting manure into gas potential source of energy, The Pennsylvania State University. J. Sci. Agric. 26 (1), $15-23$.

Razaviarani, V; Buchanan, I; Malik, S; Katalambula, H (2013). Pilot-scale anaerobic codigestion of municipal wastewater sludge with restaurant grease trapwaste. J. Environ. Manage. 123: 26-33.

Romero-Güiza, M; Vila, J., Mata-Alvarez, J; Chimenos, J; Astals, S (2016). The role of additives on anaerobic digestion: a review. Renew. Sustain. Energy Rev. 58: 1486-1499.

Shi, J; Xu, F; Wang, Z; Stiverson, JA; Yu, Z; Li, Y (2014). Effects of microbial and nonmicrobial factors of liquid anaerobic digestion effluent as inoculum on solid-state anaerobic digestion of corn stover. Bioresour. Technol. 157: 188-196.

Subramanian, B; Miot, A; Jones, B; Klibert, C; Pagilla, K (2015). A full-scale study of mixing and foaming in egg-shaped anaerobic digesters. Bioresour. Technol. 192: 461-470.

Switzenbaum, MS; Giraldo-Gomez, E; Hickey, RF (1990). Monitoring of the anaerobic methane fermentation process. Enzyme Microb Technol., 12: $722-730$.

Veeken, A; Hamelers, B (1999). Effect of temperature on hydrolysis rate of selected biowaste components. Biores. Technol., 69: 249-254.

Veeken, A; Kalyuzhnyi, S; Scharff, H; Hamelers, B (2000). Effect of $\mathrm{pH}$ and VFA on hydrolysis of organic solid waste. J. Environ. Engineer. 12: 1076-1081.

Voelklein, M AA; Jacob, R; O'Shea, JD (2016). Assessment of increasing loading rate on twostage digestion of food waste. Bioresour. Technol. 202: 172-180. 
Wei, Q; Zhang, W; Guo, J; Wu, S; Tan, T; Wang, F; Dong, R (2014). Performance and kinetic evaluation of a semi-continuously fed anaerobic digester treating food waste: Effect of trace elements on the digester recovery and stability. Chemosphere 117: 477-485.

Yang, L; Xu, F; Ge, X; Li, Y (2015). Challenges and strategies for solid-state anaerobicdigestion of lignocellulosic biomass. Renew. Sustain. Energy Rev. 44: 824-834.
Zhang, C; Su, H; Baeyens, J; Tan, T (2014a). Reviewing the anaerobic digestion of food waste for biogas production. Renew. Sustain. Energy Rev. 38: 383-392.

Zhang, C; Xiao, G; Peng, L; Su, H; Tan, T (2013). The anaerobic co-digestion of food waste and cattle manure. Bioresour. Technol. 129: 170-176. 